\title{
Triassic petroleum system as an alternative exploration concept in offshore western Timor Indonesia
}

\author{
Sugeng S. Surjono ${ }^{1} \cdot$ Rahmadi Hidayat ${ }^{1} \cdot$ Naryanto Wagimin $^{2}$
}

Received: 17 July 2017 / Accepted: 26 November 2017 / Published online: 19 December 2017

(c) The Author(s) 2017. This article is an open access publication

\begin{abstract}
Located in the north-western part of Bonaparte Basin, offshore western Timor presents the opportunity for a distinct exploration concept due to the discovery of the Abadi gas field. A classic Jurassic petroleum play did not develop as a proven reservoir and source rock in the study area due to severe erosion during the Valanginian event. Therefore, the Triassic interval requires assessment to reveal an alternative petroleum system in the study area. A petroleum system analysis utilising 2D seismic lines and three exploration wells was performed to construct a new exploration concept. The study showed that the Scythian Mount Goodwin interval could be considered a primary gas-prone source rock, with type II/III kerogen, a total organic content up to $2.09 \%$ and a hydrogen index that could reach $569 \mathrm{mg} / \mathrm{g}$. Based on a study of a pseudo-well conducted here, the Mount Goodwin interval is found to have reached gas generation in the Early Cretaceous and expulsion in the Early Eocene. The potential reservoir rocks are the Carnian-Ladinian Challis and Anisian Pollard intervals. The Challis interval, the primary reservoir, has typical shoreline sandstones and is interbedded with claystones and limestone intercalations. Petrophysical and petrographic studies in this interval indicate good reservoir properties. However, the Pollard interval mainly consists of carbonates with minor claystones and has a low quality of reservoir properties. The intraformational shale of the Challis is considered as the potential regional seal, especially within areas that are not truncated by the Valanginian event. From the perspective of exploration, the Jurassic north-east-south-west-tilted fault blocks are still favourable for new discoveries in the offshore western Timor area.
\end{abstract}

Keywords Offshore western Timor · Triassic interval · Petroleum system

\section{Introduction}

Offshore western Timor is situated to the south of Timor Island (Fig. 1), in the eastern part of Indonesia, which is adjacent to the Indonesia-Australia international border. In Australian territory, petroleum exploration and production near the study area have been well established (Charlton 2002). Many gas fields have been found since the mid1970s. The Sunrise-Troubadour gas field was discovered in approximately 1974-1975 with 8.4 trillion cubic feet (TCF)

Sugeng S. Surjono

sugengssurjono@ugm.ac.id

1 Geological Engineering Department, Faculty of Engineering, Universitas Gadjah Mada, Jl. Grafika No. 2, Yogyakarta 55281, Indonesia

2 Directorate General of Oil and Gas of the Republic of Indonesia, Plaza Centris Building, Jl. H. R. Rasuna Said Kav B-5, Jakarta Pusat 12910, Indonesia of proved and probable recoverable reserves, and this discovery was followed by another successful gas discovery of the Evans Shoal in 1988 with 6.6 TCF of proved and probable recoverable reserves (Nagura et al. 2003). These significant resources have been confirmed in the Jurassic Plover interval (Matsui et al. 2009).

In comparison with Australian operations, exploration and production activity in Indonesia are less active. In late 2000, INPEX Masela Limited discovered gas after the drilling of the Abadi-1 exploration well (Nagura et al. 2003; Zushi et al. 2009). Similar to gas fields discovered in Australian territory, the Jurassic Plover interval was also shown to be the main reservoir target. This interval is characterised by highly matured sandstone with quartzose composition (Nagura et al. 2003; Matsui et al. 2009) of typically shallow marine origin (Matsui et al. 2009). Marine shales deposited contemporaneously with the Plover formation are also postulated as primary source rocks for the Abadi gas field (Nagura et al. 2003). 
Fig. 1 a Regional tectonic setting of the Timor Sea and petroleum findings (following Charlton 2002). The black box is offshore western Timor. b Water depth map of the offshore western Timor, with the study area inside the polygon
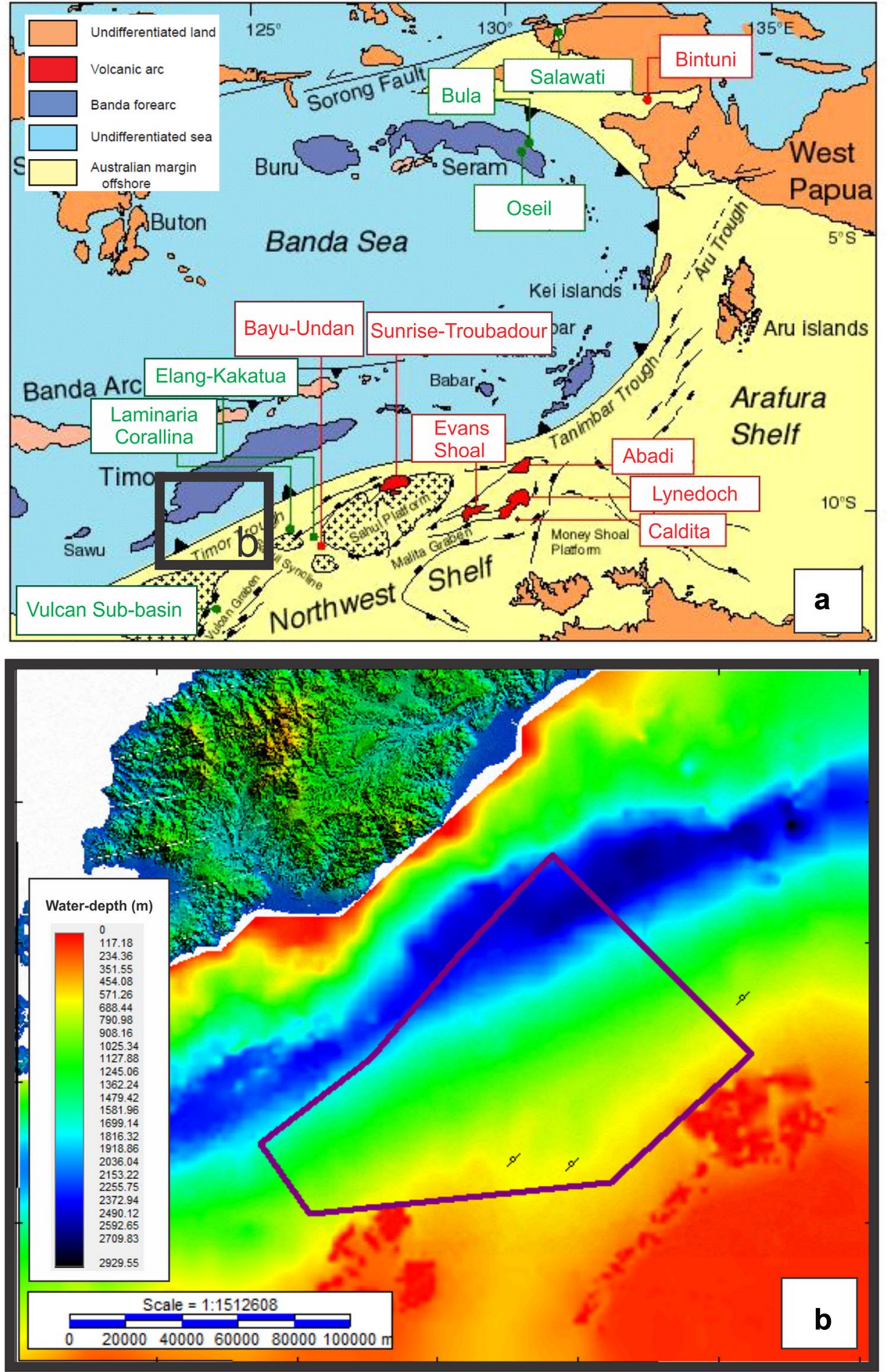

Based on the petroleum system employed in successful discoveries in both Australia and Indonesia, further exploration drilling was conducted in the research area. However, three wells were drilled but resulted in no hydrocarbon shows. Moreover, most of the wells were reported to be missing the Jurassic Plover section. In this situation, an alternative petroleum system should be proposed in order to evaluate other opportunities for petroleum discovery. An assessment in a deeper and older section, known as the Triassic interval, should be conducted to increase discovery chances within the interest area. 


\section{Methods}

This research employs the petroleum system analysis (PSA) method, which can be divided into three major analyses: (1) geochemical analysis, (2) petrophysical analysis and (3) seismic interpretation. Geochemical analysis is a standard technique in hydrocarbon exploration (Ramachandran et al. 2013), and this analysis attempts to define the quality of potential source rocks, produce 1D maturity models and estimate possible migration pathways. The petrophysical analysis defines the reservoir and seal candidate as well as their properties, such as the average effective porosity (PHIE), average volume of shale (VSH) and net-to-gross ratio (N/G). Seismic interpretation provides information related to the trapping style and structure map. Moreover, this approach can be utilised to identify productive reservoir zones (Munir et al. 2011).

After conducting these analyses, each petroleum system element can be acquired as an input for further steps. Input data are integrated to enhance the petroleum system concept within the study area.

\section{Tectonic settings}

Offshore western Timor lies on the northern Ashmore Platform of the Bonaparte Basin at the north-western part of the Australian margin. The Bonaparte Basin is a very large, structurally complex basin comprising several Palaeozoic to Mesozoic sub-basins and platform areas. The Bonaparte Basin formed during different phases of extension and compression (Bourget et al. 2012). The Ashmore Platform itself is an elevated area in the northernmost region of Bonaparte Basin. This platform is bounded by the western margin of the Vulcan sub-basin to the west and the northern flank of the Browse Basin to the south (Cadman and Temple 2003).

Most of the study area is a marginal part of the northern Ashmore Platform and is characterised by downwarping due to lithospheric flexure that has correlation to the development of the Timor Trough (Chen et al. 2012). Inside the study area, the deepest part of the Timor Trough can reach up to $2.4 \mathrm{~km}$ deep.

Offshore western Timor, which is part of eastern Indonesia, has endured complex tectonic stages (Barber et al. 2003). This region experienced a broad basinal sag during the Early Palaeozoic followed by multiple deformations and subsidences in the late Palaeozoic as a prelude to the breakup of Gondwana (Chen et al. 2012). The proto-Vulcan sub-basin and Malita graben were intensively developed at this time (Cadman and Temple 2003).
A subsequent period of significant development was the Late Permian to Middle Triassic thermal subsidence (Chen et al. 2012), followed by the Late Triassic compressional event (Cadman and Temple 2003). This event, known as the Fitzroy Movement, was probably related to the breakup events along the Gondwanan margin or the docking of continental blocks along the adjacent Irian Jaya (Papua) subduction margin (Longley et al. 2002).

The Middle to Late Jurassic north-west-south-east extension created major north-east-south-west-trending depocenters, such as Vulcan sub-basin, Malita graben and high areas of the Ashmore Platform and the Londonderry High (Chen et al. 2012). This extension corresponds to a continental breakup phase (Cadman and Temple 2003) and syn-rift sediment infilling. The later Early Cretaceous post-breakup phase commenced as a result of the onset of the Greater India separation (Longley et al. 2002). This event triggered the Valanginian massive erosion and truncation (Amir et al. 2010) in the northern part of the Ashmore Platform.

Regional compression associated with the collision of Australian-Southeast Asian microplates occurred in the Miocene, inducing the formation of the Timor Trough (Cadman and Temple 2003) and strongly deforming the northern margin of the Ashmore Platform. According to Keep et al. (2002), three main pulses were recorded at 25, 8 and $3 \mathrm{Ma}$. The first event corresponds to the collision of the New Guinea region of the Australian plate with the Philippine Sea Plate. The second event corresponds to a collision between a microcontinental fragment and the Banda Arc. The latest event is the main compressional phase in Papua New Guinea.

\section{Stratigraphy}

The regional stratigraphy of the Timor Sea and its main tectonic events are summarised in Fig. 2. The seismic markers and $\log$ analyses carried out in this study are also calibrated to this stratigraphy column. The oldest unit penetrated by drilling on the offshore western Timor is the Late Permian section, which is composed of the Kazanian Cape Hay and Tatarian Dombey intervals. The Cape Hay interval contains siltstones with claystones and minor limestones that were deposited under marine shelf conditions. This interval is coeval with the predominantly coarse siliciclastic sections in the south-east of the Bonaparte Basin (Mory 1991). Overlying the Cape Hay, a broad open marine carbonate platform along the northern margin of the Bonaparte Basin was established, forming the Tatarian Dombey interval, which is mainly composed of mudstones-packstones with minor claystones.

The regressive phase commenced after the Late Permian section, marking the end of the Palaeozoic tectonic

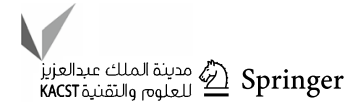


Fig. 2 Regional stratigraphy, structural style and main tectonic events of the study area (Keep et al. 2002; Longley et al. 2002; Cadman and Temple 2003; Chen et al. 2012 with modification) calibrated with seismic marker and well log analysis

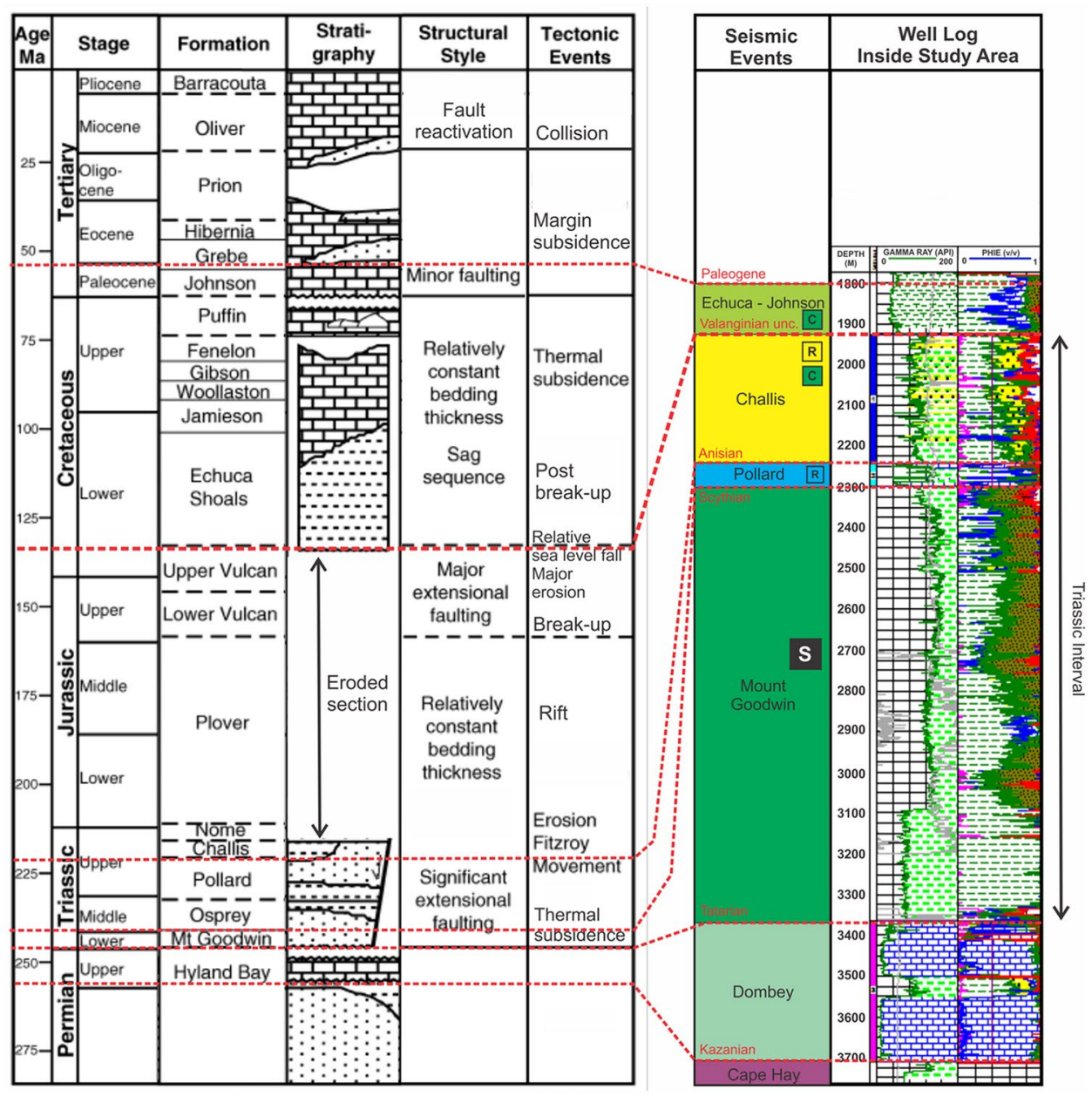

activity (Mory 1991). This phase produced thick, siliciclastic-carbonate Triassic section facies that cover the Vulcan sub-basin, Londonderry High and Ashmore Platform (Cadman and Temple 2003). Beginning in the Scythian, the Mount Goodwin interval was deposited with interbedded claystones and minor siltstone-limestones. Following the Mount Goodwin intervals, shallow Anisian Pollard marine carbonate and shoreline mixed with siliciclastic-carbonates of the Carnian-Ladinian Challis interval exhibit complex shallow marine facies, and both intervals have the potential to serve as good reservoirs (Cadman and Temple 2003). Based on log reports, the Pollard interval consists of mudstones with some claystones, while the Challis interval is more sand-prone with interbedded claystones and limestone intercalations.

The Valanginian event, a regional unconformity, is marked as the boundary between the Triassic section and the overlying Cretaceous-Cenozoic section. This event represents a non-depositional hiatus in the Vulcan sub-basin in elevated areas such as the Ashmore Platform and Londonderry High, creating a large erosional surface due the relative fall in sea level (Mory 1991). Most of the well data in this study area recorded a removal of the entire Jurassic and the upper part of the Triassic interval.

Beginning in the Cretaceous to the Early Tertiary, outer shelf carbonates developed widely in the north-western part of Bonaparte Basin (Mory 1991). This region exhibits a prograding basin wedge of fine-grained clastic and carbonate sections punctuated by several unconformities resulting from sea level fluctuations across the offshore region of Bonaparte Basin (Cadman and Temple 2003).

\section{Triassic petroleum system analysis}

\section{Source rock}

Previous regional studies have indicated that the source rock potential of eastern Indonesia, which ranges from the Arafura Sea to the north-west shelf of Australia, may have developed in the Late Palaeozoic to Early Mesozoic. Late Triassic calcareous shales are the most favourable source rocks because these contain a total organic content (TOC) up to $15.9 \%$, while their hydrogen index (HI) is in the range 
of 441-654 mg/g. These shales are likely to be deposited in a restricted marine setting (Livsey et al. 1992). Calcareous shales and coal intervals are also potential humic source rocks with TOC $31.4-66.5 \mathrm{wt} \%$ and HI of $235-262 \mathrm{mg} / \mathrm{g}$ (Livsey et al. 1992).

According to geochemical data from wells in the surrounding area, the primary source rocks are the Triassic thick fossiliferous claystones known as the Scythian Mount Goodwin interval. This interval is gas-prone (type III kerogen) with minor oil- and gas-prone zones (type II/III kerogen). Claystone samples taken from the wells mainly have fair gas source potential and appear to contain marinederived organic matter with minor terrestrial input. The TOC of these samples is up to $2.09 \%$, and the HI can reach up to $569 \mathrm{mg} / \mathrm{g}$.

Burial history analysis from pseudowell in the depocenter area has been conducted to predict the timing of hydrocarbon generation and expulsion. According to Nwankwo et al. (2012), heat flow data calculations on data provided by wells are essential to evaluate the petroleum potential of a particular basin. In establishing a burial history model, a $1.0 \%$ vitrinite reflectance threshold, a gas window temperature of $150{ }^{\circ} \mathrm{C}$ and a heat flow estimation of $50 \mathrm{~mW} /$ $\mathrm{m}^{2}$ were used. Pseudo-wells located at the margin of the Timor Trough were constructed to counter the maximum depth uncertainty. The results indicate that the Mount Goodwin interval reached the onset of gas generation 124 million years ago (Ma), during the Early Cretaceous (Fig. 3a), and that gas expulsion began at $50 \mathrm{Ma}$, during the Early Eocene (Fig. 3b). Further burial history analysis indicates that deep water column due to the downwarping of the Timor Trough does not necessarily correspond to source rock maturation within the study area. In this case, the thickness of the overburden rocks seems to be a parameter that significantly influences source rock maturation.

\section{Migration}

Regional studies on the Ashmore Platform propose three scenarios for hydrocarbon migration: (1) long-range migration from adjacent proven depocenters in the south of study area; (2) unproven source rock in the Triassic interval; or (3) possible thin Jurassic source rocks that might be present in remnant Palaeozoic grabens and provide local pods (Cadman and Temple 2003). Based on the geochemistry revealed through this research, the Triassic interval can be concluded to be the most promising resource in offshore western Timor.

Long-range migration appears unlikely because the greatest downwarping of the Timor Trough is located in the south of the study area. This feature significantly limits the possibility of charging from proven southern depocenters such as the Swan or Caswell sub-basins. The Valanginian event has a major impact on the existence of Jurassic source rock.
Seismic interpretation suggested this event as a broad truncated surface that causes severe erosion in the Jurassic interval. Even if the Jurassic interval still exists, there remains a question as to whether the thickness of this interval will enable it to give a sufficient charge towards the study area.

\section{Reservoir rock}

The Carnian-Ladinian Challis sandstones are the primary reservoir target for this study area. These sandstones exhibit a complex shoreline environment and are occasionally mixed with carbonate stringers. The petrographic study indicates that these sandstones are mainly lithicarenite and are characterised as being medium grained, moderately well sorted, sub-rounded and quartz rich with common mica minerals and intragranular porosity. Based on the laboratory measurement of this reservoir has revealed a maximum porosity of up to $29 \%$ and a permeability of $305 \mathrm{mD}$ (Bandjarnahor et al. (2000). The petrophysical analysis shows good quality and a thick reservoir with an average PHIE of $18-20 \%$ and an N/G of 24-28\% (Fig. 4).

Anisian Pollard carbonates could be the secondary target for reservoir rock. However, inside the study area, these layers appear to have thin and relatively poor properties. The petrophysical analysis suggested an average PHIE of 6-10\%, a maximum gross thickness of 58-69 $\mathrm{m}$ and an average N/G of $10-32 \%$. It can be concluded that Anisian Pollard carbonates are potentially unfavourable for reservoir rock inside the study area, but these formations may have potential in other areas within offshore western Timor.

\section{Seal rock}

Intraformational shales of the Challis interval are proposed to be the primary seal for both the Challis and Pollard reservoirs. According to M-1 well report, laboratory analysis of this interval has revealed a high seal capacity potential with a threshold pressure of 5986.2 psia, a porosity of $7.1 \%$ and a permeability of $0.016 \mathrm{mD}$, and it has been estimated that intraformational shales could hold as much as $561 \mathrm{~m}$ of the gas column.

Although the seal rock of Challis has good capacity, the lateral continuity is questionable due to severe truncation in the Valanginian event. If this seal interval is eroded, the younger Late Cretaceous Wangarlu marl interval is suggested to be the secondary seal rock and actually has better lateral continuation within the research area. Bandjarnahor et al. (2000) has informed that this interval has slightly poorer properties than the primary seal rock, with a 
Fig. 3 1D Burial history analyses: a vitrinite reflectance model suggests gas generation (threshold $1.0 \%$ ) at $124 \mathrm{Ma}$ and b thermal model suggests gas expulsion (threshold $150{ }^{\circ} \mathrm{C}$ ) at $50 \mathrm{Ma}$
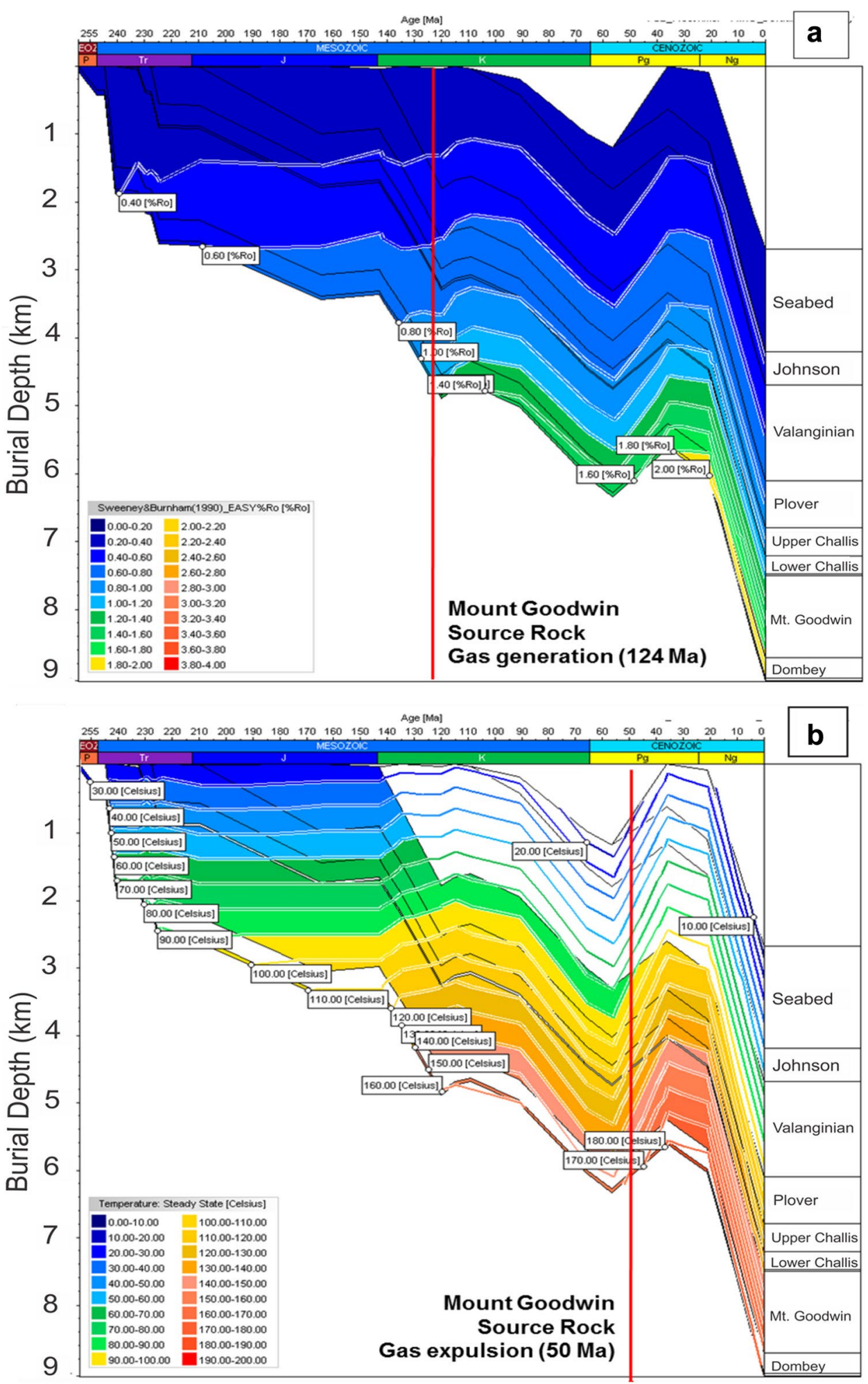

threshold pressure of 3027.3 psia, permeability of $0.063 \mathrm{mD}$ and a predicted $294.5-\mathrm{m}$ column gas-holding column.

\section{Trap}

In general, the tilted northeast-southwest-trending fault blocks that commenced during the Jurassic period are considered the most significant traps, and these features 


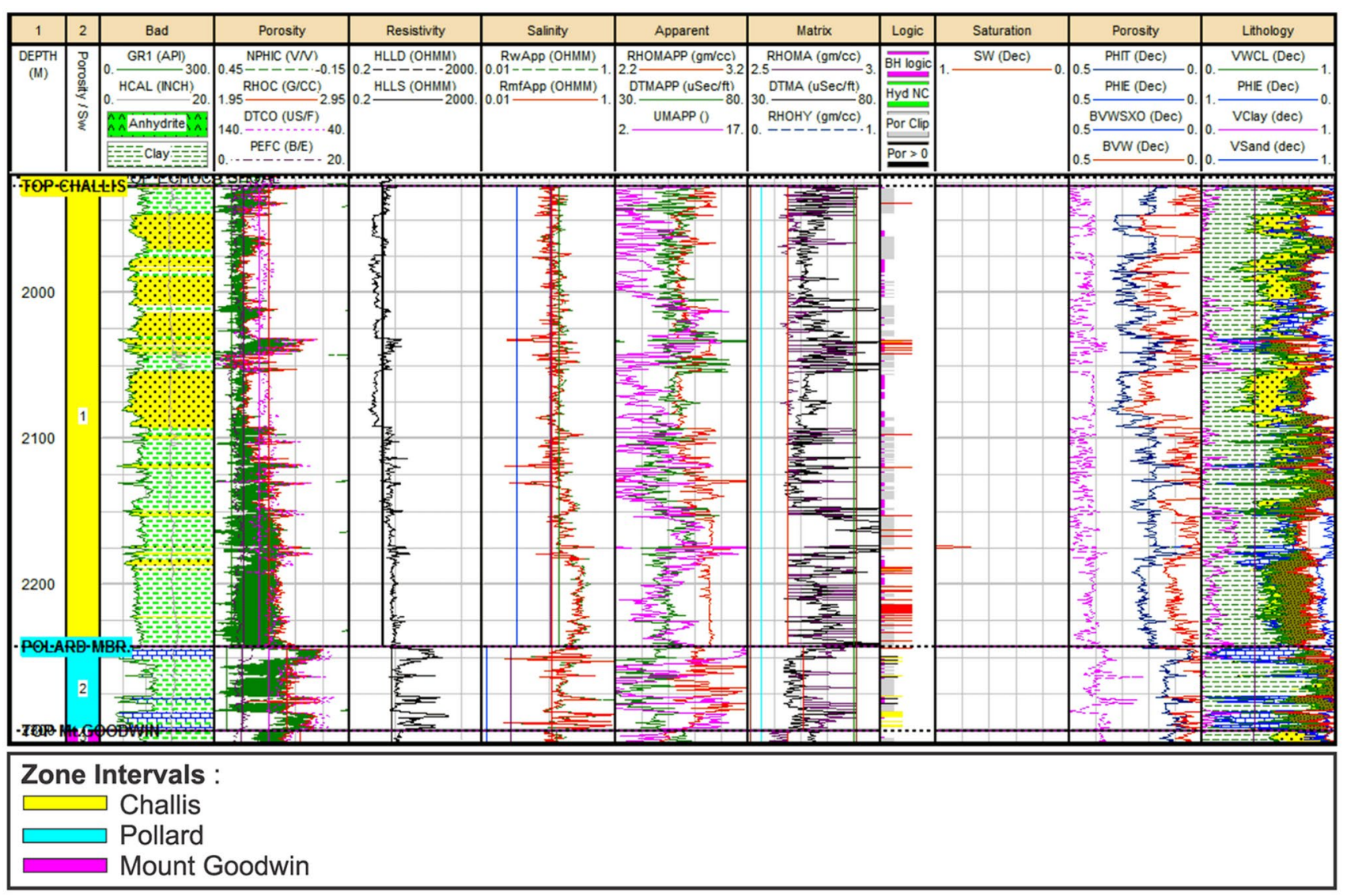

Fig. 4 Petrophysical analysis of Carnian-Ladinian Challis interval (yellow zone) of M-1 well indicates good porosity of reservoirs

Fig. 5 Interpretation of northwest-southeast seismic lines in the study area revealed tilted fault blocks that are potential traps

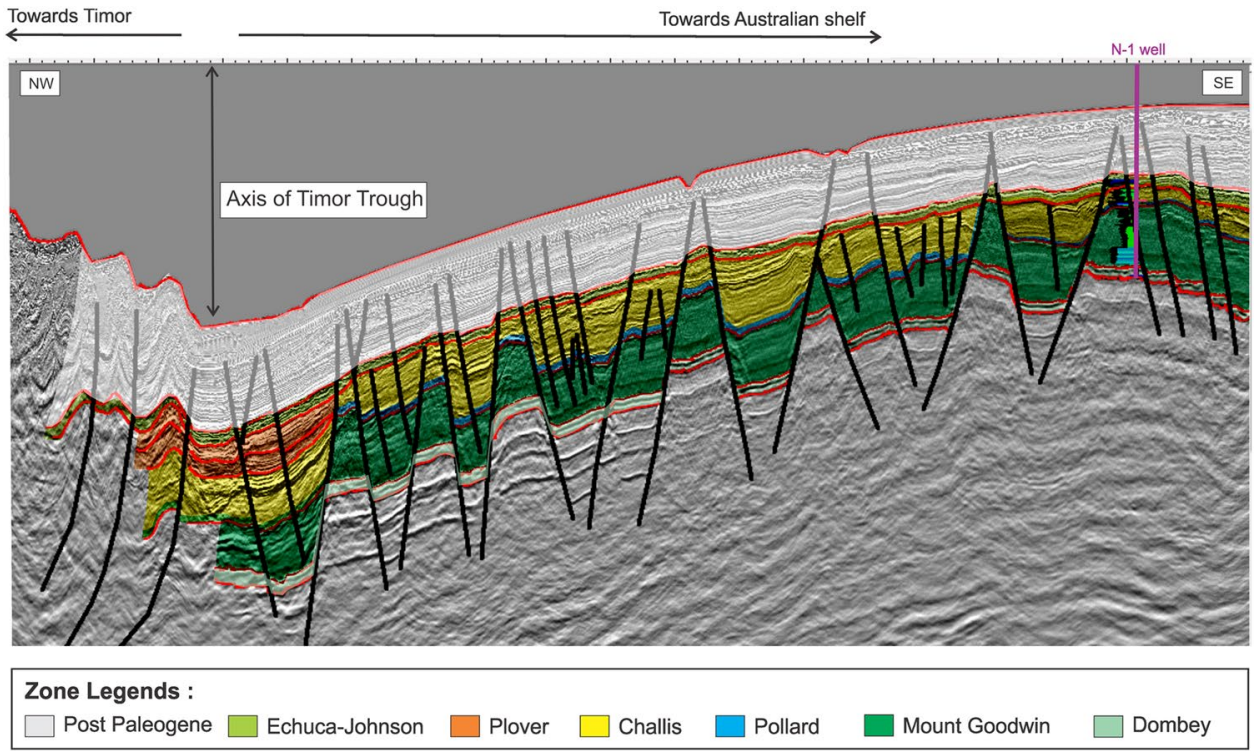

have become the primary exploration objective in the Ashmore Platform (Cadman and Temple 2003). In seismic sections, the fault blocks are well preserved, creating several horst-graben systems with narrow, vertical and large throw (Fig. 5). In these terms, these faults have a high potential to be adequate traps for oil or gas. The structure of the northern Ashmore Platform is dominated by flexural deformation during the development of the 
Timor Trough and exhibits highly complex deformation and large reactivation that affect the seafloor (Chen et al. 2012). These features can significantly increase the faulttrap risk within the study area and are analogous to the adjacent hydrocarbon traps such as the Laminaria High and Nancar Trough that have been shown to be underfilled or completely breached (Castillo et al. 2002).

Based on this study, the closures that have already been drilled with no hydrocarbon shows have a strong link to the restriction of the migration pathway. The existence of block-faulted areas with major throw has strictly confined the south-westward migration from the possible source pods located in the northern part (the Timor Trough) towards the closure. Unsuccessful drilled closures prove that hydrocarbons derived from northern source pods have limited pathways and could not migrate towards these closures.

\section{Petroleum event chart}

The Scythian Mount Goodwin, comprising marine-derived claystones, has the potential to be the main gas-prone source rock. The Carnian-Ladinian Challis sandstones are believed to be the main reservoir target due to their high-quality petrophysical properties. Anisian Pollard carbonates could be a secondary reservoir, but this suggestion requires confirmation because of the poor qualities of this interval in the exploration wells inside the study area. The good seal capacity of the Carnian-Ladinian Challis intraformational shales could be optimised as the main seal despite the risk of massive erosion caused by the Valanginian event. Triassic tilted north-east-south-west fault blocks are still promising as the main traps to be targeted for drilling. The critical event, as indicated by the assessment of these local petroleum system elements, occurred during the Early Eocene. This timing is similar to gas expulsion and gas preservation of the Mount Goodwin source rock, which was the last event that has been established within the study area (Fig. 6).

\section{Conclusion}

A Triassic petroleum system is proposed in this research as a new concept applied to offshore western Timor due to the missing prolific Jurassic interval. Petroleum system analysis was conducted in this study, and the results reveal that the Triassic section comprising the Mount Goodwin, Pollard and Challis intervals is feasible as an alternative target for further exploration development in offshore western Timor.

However, several challenges and limitations in offshore western Timor must be thoughtfully observed and considered to minimise the geological risk factor. For instance, the

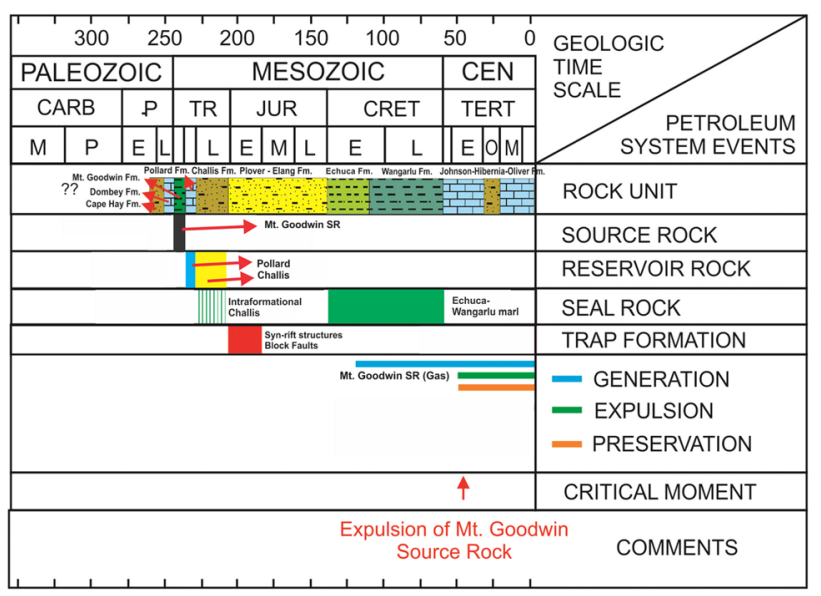

Fig. 6 Local petroleum event chart for offshore western Timor. The timing of the Mount Goodwin expulsion is expected as the critical moment

south-westward migration proposed in this study should be accurately delineated to locate hydrocarbon-filled closures. Several dry hole wells in the study area are believed to serve as an uncertain migration path from a northern postulated source pod.

Acknowledgements Acknowledgements are addressed to Ditjen MIGAS RI (Directorate General of Oil and Gas of the Republic of Indonesia) for granting permission to utilise proprietary government data and information. The authors would like to thank the team members of LKFT UGM (Lembaga Kerjasama Fakultas Teknik, Universitas Gadjah Mada/Cooperation Agency of Engineering Faculty) for supporting the analyses and technical discussions.

Open Access This article is distributed under the terms of the Creative Commons Attribution 4.0 International License (http://creativecommons.org/licenses/by/4.0/), which permits unrestricted use, distribution, and reproduction in any medium, provided you give appropriate credit to the original author(s) and the source, provide a link to the Creative Commons license, and indicate if changes were made.

\section{References}

Amir V, Hall R, Elders CF (2010) Structural evolution of the northern Bonaparte Basin, northwest shelf Australia. In: Proceedings, Indonesian Petroleum Association 34th Annual Convention \& Exhibition, IPA, May 2010

Bandjarnahor HMP, Kihara K, Nishida H (2000) Final geological well report M-1. Inpex Rabe Timor Sea Ltd (Unpublished)

Barber P, Carter P, Fraser T, Baillie P, Myers K (2003) Paleozoic and Mesozoic petroleum systems in the Timor and Arafura Seas, Eastern Indonesia. Proc Annu Conv-Indones Pet Assoc 29(1):1-16

Bourget J, Ainsworth RB, Backé G, Keep M (2012) Tectonic evolution of the northern Bonaparte Basin: impact on continental shelf architecture and sediment distribution during the Pleistocene. Aust J Earth Sci 6:877-897

Cadman SJ, Temple PR (2003) Bonaparte Basin, NT, WA, AC \& JPDA, 2nd edn. Geoscience Australia, Canberra 
Castillo DA, Bishop DJ, de Ruig M (2002) Fault seal integrity in the Timor Sea area: prediction of trap failure using well-constrained stress tensors and fault surfaces interpreted from 3D seismic. Proc Annu Conv-Indones Pet Assoc 28(1):261-288

Charlton TR (2002) The petroleum potential of West Timor. Proc Annu Conv-Indones Pet Assoc 28(1):301-317

Chen G, Hill KC, Hoffman N, O'Brien GW (2012) Geodynamic evolution of the Vulcan Sub-basin, Timor Sea, northwest Australia: a pre-compression New Guinea analogue? Aust J Earth Sci 6:719-736

Keep M, Clough M, Langhi L, Moss SJ (2002) Neogene tectonic and structural evolution of the Timor Sea region, NW Australia. In: The sedimentary basins of Western Australia 3: proceedings of the petroleum exploration society of Australia symposium vol 3, pp 341-353

Livsey AR, Duxbury N, Richards F (1992) The geochemistry of tertiary and pre-tertiary source rocks and associated oils in eastern Indonesia. Proc Annu Conv-Indones Pet Assoc 21(1):499-520

Longley IM, Buessenschuett C, Clydesdale L, Cubitt CJ, Davis RC, Johnson MK, Marshall NM, Murray AP, Somerville R, Spry TB, Thompson NB (2002) The north west shelf of Australia-a woodside perspective. In: The sedimentary basins of Western Australia: proceedings of the petroleum exploration society of Australia symposium vol 3, pp 1-88

Matsui R, Shinbo E, Omokawa M, Zushi T (2009) Quartz cementation and reservoir quality of the Plover sandstone in the Abadi gas field. Proc Annu Conv-Indones Pet Assoc 33(1)
Mory AJ (1991) Geology of the offshore Bonaparte Basin, northwestern Australia. Department of Mines Western Australia, Perth

Munir K, Iqbal MA, Farid A, Shabih SM (2011) Mapping the productive sands of Lower Goru Formation by using seismic stratigraphy and rock physical studies in Sawan area, southern Pakistan: a case study. J Petrol Explor Prod Technol 1(1):33-42

Nagura H, Bandjarnahor HMP, Suzuki I, Kihara K, Teramoto T, Swiecicki T, Hayashi Y, Bird R, Yoshida T (2003) The Abadi gas field. Proc Annu Conv-Indones Pet Assoc 29(1):1-16

Nwankwo CN, Emujakporue GO, Nwosu LI (2012) Evaluation of the petroleum potentials and prospect of the Chad Basin Nigeria from heat flow and gravity data. J Petrol Explor Prod Technol 2(1):1-6

Ramachandran K, Babu V, Behera BK, Harinarayana T (2013) Source rock analysis, thermal maturation and hydrocarbon generation using rock-eval pyrolysis in parts of Krishna-Godavari Basin, India: a case study. J Petrol Explor Prod Technol 3(1):11-20

Zushi T, Takano S, Suzuki I (2009) Reservoir architecture of the Abadi gas field. Proc Annu Conv-Indones Pet Assoc 33(1):IPA09-G-027

Publisher's Note Springer Nature remains neutral with regard tojurisdictional claims in published maps and institutional affiliations. 